\title{
ARTYKULY
}

\author{
Maria Wieruszewska
}

\section{O potrzebie badań nad percepcją wizualną krajobrazu kulturowego wsi}

$\mathrm{W}$ artykule omówiono wybrane kwestie związane z badaniami wizualnej percepcji krajobrazu kulturowego wsi. Autorka dokonała analizy w świetle trzech zwrotów, a mianowicie: kulturowego, ikonicznego i przestrzennego. Podkreśliła, że zdegradowane środowisko wiejskie oraz zniszczony krajobraz kulturowy są dowodem błędnych założeń teoretycznych i metodologicznych. Wskazała, że niewłaściwe wzorce planowania przestrzennego są konsekwencją braku humanistycznego spojrzenia w badaniach struktur przestrzennych. Główną osią narracji autorki stał się problem niedoboru takich wartości, jak: przywiązanie do miejsca, tradycja, szacunek dla przestrzeni w jej historycznych i geograficznych aspektach. Z refleksji tej wynika bezpośrednio, że humanistyczne podejście jest bardzo potrzebne do wdrożenia geografii z ,ludzką twarzą".

Według autorki, która podziela zdanie Rogera Scrutona, ochrona wiejskiego krajobrazu kulturowego wymaga docenienia tradycyjnych wartości kulturowych. W artykule wskazano także na obserwowaną wśród młodych badaczy tendencję do umniejszania roli percepcji wizualnej. Autorka kwestionuje „kulturę detronizacji” wzroku, który jako element doświadczania przestrzeni przez człowieka $\mathrm{w}$ istotny sposób pomaga $\mathrm{w}$ walce przeciwko degradacji krajobrazu polskiej wsi.

Słowa kluczowe: zwrot kulturowy, zwrot ikoniczny, zwrot przestrzenny, wieś, wartości.

Poniższy tekst stanowi próbę wytłumaczenia motywów wyboru tematu w ramach projektu badawczego, zakończonego zbiorową publikacją (Bukraba-Rylska, Wieruszewska, Burdyka 2017). Czas, który minął od postawienia w niej ostatniej kropki ${ }^{1}$, otworzył możliwość pogłębienia refleksji, którą - moim zdaniem - warto

\footnotetext{
${ }^{1}$ Publikację i badania sfinansowano ze środków Naukowego Centrum Nauki, przyznanych na podstawie decyzji nr DEC-2014/13/B/HS2/00832. Jestem autorką rozdziałów: Krajobraz kulturowy wsi w percepcji wizualnej oraz The Rural Cultural Landscape in Visual Perception, zawartych we wspomnianej publikacji zbiorowej (zob. Wieruszewska 2017a, 2017b).
} 
wyartykułować, tym bardziej że przekracza ona zakres postawionego w książce zadania, czyli opracowania wyników badań empirycznych. $Z$ tego względu swoje przemyślenia, dotyczące percepcji wizualnej krajobrazu kulturowego wsi, traktuję jako poszerzenie i uzupełnienie wątków, które w książce są tylko sygnalizowane.

W proponowanej refleksji będę podążała tropem zmian, które zyskały miano zwrotu kulturowego (cultural turn) i powiązanych z nim dwóch innych zwrotów ikonicznego (iconic turn) i przestrzennego (spatial turn). W odniesieniach do krajobrazu kulturowego wsi jak w soczewce zbierane są implikacje tych nowych orientacji badawczych (Libura 1990, Bachmann-Medick 2012). Wieś, w jej aspekcie przestrzennym, uważam za kategorię kluczową dla prowadzonej tu narracji, ponieważ skupia wspomniane efekty reorientacji, wyraźnie dostrzegane $\mathrm{w}$ humanistycznym nastawieniu badawczym. Trzy wymienione powyżej terminy odciskają swoje wyraźne piętno na problematyce związanej z hasłem „wieś”. Poszerzają horyzont możliwych badań, choć z drugiej strony trzeba przyznać, że jak na razie w polskich realiach nie idzie za tym rzeczywiście odmieniona praktyka. Jest tak po części dlatego, że jak pisze konserwatysta R. Scruton, ,postępowo myślący ludzie zrobili, co mogli, aby [wieś - przyp. M.W.] zmarginalizować, uznając za przeszkodę dla radykalnych rozwiązań [...]" (Scruton 2017, s. 213). Istnieje więc wyraźna niewspółmierność możliwości problematyzowania zagadnień wsi i badań podejmowanych faktycznie w tym zakresie.

Zwrot kulturowy to pojemne sformułowanie, któremu ton nadaje antypozytywistyczny przełom w nauce. Rzecz polega na tym, że badacz świata ludzkiego (ale nie tylko) świadomie rezygnuje $\mathrm{z}$ ujęcia, którego wzorem było dążenie do osiągnięcia wiedzy obiektywnej, prawdziwej, pewnej. Rozumie bowiem, iż warsztat, jakim się posługuje, nie gwarantuje tego, czemu niegdyś patronowały „mędrca szkiełko i oko" oraz scjentystyczne roszczenia do uzyskania takiej wiedzy. Ze względu na świadomość niemożności dotarcia w badaniach społecznych do tzw. nagich faktów jednocześnie urealnia się przekonanie, iż badacz ludzkiego świata (społecznego) ma zawsze do czynienia - po stronie ontologii i epistemologii - z danymi w jakiś sposób przetworzonymi i wcześniej już zinterpretowanymi. To pierwszy sygnał roli kultury w budowaniu wiedzy i formułowaniu założeń filozofii poznania.

Można potwierdzić, że kultura to komunikowanie. Odwołując się do mojego ulubionego rozumienia kultury, należy zaznaczyć, że ma ona swój odległy źródłosłów w łacińskim wyrazie communicare, który trafnie ilustruje, na czym rzecz polega w przypadku kultury. Bez względu bowiem na kontekst czasu i przestrzeni, istotą sprawy jest zawsze bycie w relacji. Myślę więc o pojmowaniu kultury, 
odnoszącym się do zasobu, z którego ludzie czerpią interpretacje sytuacji, w jakich się znajdują, a równocześnie obejmujące reguły więzi, w ramach których ludzie się między sobą komunikują. Mówi się, że zwrot kulturowy jest „dzieckiem postmodernizmu". Równie uprawnione byłoby stwierdzenie odwrotne, czyli że postmodernizm jest skutkiem kulturowego zwrotu.

Kiedy staramy się dociec początku intelektualnych inspiracji, które miały wpływ na orientację kulturalistyczną w socjologii, to w sposób oczywisty odwołujemy się do klasyków, takich jak: Émile Durkheim, Alexis de Tocqueville, Ferdinand Tönnies, David Riesman, ale także Florian Znaniecki. To tylko wybrani, nieliczni myśliciele w historii myśli społecznej, którzy przywiązywali wagę do kulturowych impoderiabiliów. Łączy ich to, że nie redukowali zjawisk społecznych do działań jednostkowych, lecz dostrzegali wagę tego, co spaja ludzi między sobą i co jako system aksjonormatywny (w ujęciu Znanieckiego) wypełnia pole społeczno-indywidualnych relacji. Przy tym znaleźli oni miejsce, w pozytywistycznie ukształtowanej socjologii, dla współczesnych badań wartościujących (appreciative inquiry) i działań mających na celu zrobienie użytku z triady: zrozumieć-docenić-chronić. Wzorcowym przykładem powiązania tych elementów w ochronie środowiska wiejskiego jest Anglia (Scruton 2017). Rozpoznanie zagrożeń krajobrazu wiejskiego - spowodowanych złym zarządzeniem - skłaniało do podejmowania tam wielu bardzo skutecznych lokalnych inicjatyw, które budziły zbiorową troskę o najbliższe otoczenie. Sprawdzona postawa ojkofilii - nie z racji sentymentu czy nostalgii, ale żywego przywiązania do domu i wspólnoty - była i jest najlepszą drogą do rozwiązywania współczesnych problemów środowiska nie tylko na Wyspach Brytyjskich. Ta linia argumentacji stała się też główną przesłanką skierowania uwagi na percepcję wizualną krajobrazu. Dostrzeżenie piękna wywołuje odruch szacunku. W brytyjskim życiu publicznym krajobraz stał się źródłem „miłości do ziemi jako «osobo-obrazu», będącego jednocześnie naturą i cywilizacją, miejscem wspólnym i ogrodzonym, polem dla wolności i symbolem prawa" (Scruton 2017, s. 321).

W tym miejscu warto uczynić dygresję, demaskującą obciążający współczesnych planistów przestrzennych gorset wiedzy, który hamuje twórczą wyobraźnię, utrudnia wykazywanie się kreatywnością, pozbawia wizji, zastępując ją w praktyce rutyną złych wzorów lub pasywnością. W Polsce coraz częściej daje się słyszeć utyskiwanie na niewłaściwy kierunek ewolucji zagospodarowania przestrzennego, deficyt pomysłów na lepszy, alternatywny model osadnictwa w celu uniknięcia niekontrolowanej suburbanizacji i ,patologii zabudowy rozproszonej”, co pogłębia degradację, chaos, destrukcję i deformację przestrzeni wsi. Korzystam z uwag M. Kowickiego, który porównuje układy osadnicze, tworzone na tzw. 
surowym korzeniu (jak np. w gminie Nowosolna w województwie łódzkim), które odznaczały się zwartą, regularną i zaprojektowaną wraz z rozłogiem pól geometryczną zabudową, ze współczesnym zdeformowaniem krajobrazu, pomimo ochrony konserwatorskiej. Trudno nie przyznać autorowi racji, iż jest to efekt nie tylko samych praktyk planistycznych, ale również stojących za nimi błędnych przesłanek, iż „wieś jest bytem anachronicznym i podtrzymanie jej egzystencji mija się z celem" (Kowicki 2011, s. 76 i nast.). W tych złych praktykach przestrzennych manifestuje się ojkofobia jako jeden z fenomenów tzw. kultury wyparcia, tj. wyrzekania się domu, lojalności, przywiązania. Pogarda dla takich wartości, jak: tradycja, dom, rodzina, naród, wspólnota - wartości lekceważonych, dyskredytowanych, ośmieszanych, wyszydzanych - jest cechą obecnej poprawności politycznej, promowanej w aurze ,postępu" i - wątpliwych moim zdaniem - dyrektyw dotyczących planowania przestrzennego. Takie cnoty, jak: gospodarność, czystość, ład, przyjazne nastawienie do innych, sprawdzają się w doświadczeniu przestrzeni, którą uważamy za „naszą”. Ludzie mający wspólną przestrzeń wsi, potwierdzają tę formę lojalności, która jest definiowana poprzez dom, ziemię, osiadłość. To podstawa ojkofilii, wyzwalająca też poczucie odpowiedzialności. Powtórnie wypada wskazać na Anglię, w której wcześnie dostrzeżone skutki rozrastania się miast kosztem terenów rolniczych doprowadziły do uchwalenia w roku 1946 r. ustawy o planowaniu przestrzennym miast i wsi. R. Scruton, przypominając czas po tym wydarzeniu, twierdzi, iż porównanie obecnej Anglii z Holandią czy Belgią daje obraz tego, jak ,ogromne korzyści ekologiczne wyniknęly z tej ustawy" (Scruton 2017, s. 324).

Czyniąc przeskok w czasie, można zauważyć, iż schyłek XX w. uwydatnił znaczenie pojęcia wartości postmaterialistycznych, którymi zaczęto się kierować w najbardziej rozwiniętych społeczeństwach. Przesunięcie perspektywy z wcześniej ograniczonych horyzontów dyscyplin, które coraz mniej wyjaśniały albo „nader szybko wyjaśniały niemal wszystko”, poszerzyło spektrum nowych orientacji badawczych w kierunku humanistyki (Libura 1990, s. 11 i nast., Bachmann-Medick 2012, s. 62). Zwrot polegający na przejściu od „twardych” zainteresowań o charakterze ekonomicznym w stronę „miękkich" wartości kulturowych stanowił efekt wyczerpania się dawnych wyjaśnień „strukturalnych i instytucjonalnych”. Jednocześnie był to symptom nowych wyzwań intelektualnych (Sztompka 2007, s. 41 i nast.). Niekiedy przejawiał się on jako postulat ,antropologizacji”, czasem „większej antropologizacji” badań - miało to podkreślać wiodącą rolę człowieka w tym, co stanowi przedmiot, a zarazem podmiot badania.

Narastające przekonanie, że kultura ma duże znaczenie, ponieważ pełni kluczową funkcję we wszystkich procesach społecznych, gospodarczych, cywiliza- 
cyjnych, chociaż nie każda dyscyplina potrafi to badawczo wykorzystać, jest coraz powszechniejsze ${ }^{2}$. Wskazałam, iż kulturę można sprowadzić do komunikowania - w czasie i przestrzeni. Warto na tym tle odnotować zmieniony charakter współczesnego porozumiewania się ludzi na skutek szybkich efektów swego rodzaju kompresji czasu i przestrzeni, co jest rezultatem globalizacji. W ulegającym temu procesowi świecie coraz rzadziej istnieją możliwości niezakłóconej komunikacji, czyli takiej, w której sens i treść przekazu, wychodzące od nadawcy komunikatu, byłyby właściwie, tj. odbierane zgodnie z intencją mówiącego. Kakofonii głosów w technologicznie wspomaganym polu cyberprzestrzeni nie wtóruje zdolność prawidłowego odczytywania sensu docierających treści. Szum informacyjny na skutek wzrastającej liczby informacji, efektów zamierzonej i niecelowej manipulacji, uproszczeń, stereotypów powoduje poczucie niepewności. „Anonimowość innych zwiększa poczucie niepewności: nie wiemy, co zrobią, jak się zachowają, czy spełnią nasze oczekiwania" (Sztompka 2007, s. 383). Tak w skrócie przedstawiają się racje za odwołaniem się do kultury jako do ram zrozumiałego dla ludzi świata. W ten sposób można też postrzegać niezbędność metarefleksji, której fundamentem nie jest wiedza ekspercka, odniesiona do wąskiej specjalizacji, ale taka, która pobudza do myślenia, naprowadza na właściwy trop, nie zamyka się na intuicję i jest otwarta na wyzwania. Istotą rzeczy są zatem kultura i jej kreatywny potencjał. Logika kultury staje się czymś niezwykle aktualnym i ważnym w kontekście nowej wyobraźni społecznej, także dotyczącej wsi. To otwiera drogę do poszukiwania wiedzy, która mogłaby być gromadzona obok trochę skostniałych czy dogmatycznych reprezentacji nauki.

Jeśli tezę, że globalizacja niszczy zaufanie, uznamy za prawdziwą, to odwrotną stroną wywoływanych przez nią konsekwencji w życiu społecznym byłby stan zadomowienia i familiarności, oswojenia poprzez „spoistość normatywną”, łatwość odwołania się do podzielanych wartości ${ }^{3}$. Widać to na przykładzie konkretnych przestrzeni, będących ramami dla codziennego życia mieszkańców poszczególnych wsi w Polsce. Na tle stereotypowego, utrwalonego w socjologii przekonania o dezintegracji małych wspólnot lokalnych, w tym wsi, jako nieuniknionych następstw przemian społeczeństwa tradycyjnego w nowoczesne, uwagę

2 J. Wilkin otwarcie przyznaje, iż prawie (to ,,prawie” czyni różnicę) każdy ekonomista wie, że kultura ma znaczenie, lecz nie każdy potrafi wyjaśnić, w czym dokładnie się ono przejawia (Wilkin 2016, s. 95).

${ }^{3}$ Należy tu przypomnieć, że kultura to kult wartości. Pluralizm aksjologiczny nie jest funkcjonalny wobec ,drogowskazów etycznych, estetycznych czy ideowych, na otwartej, słabo ustrukturalizowanej globalnej pustyni" (Albrow 1996, za: Sztompka 2007, s. 387). 
przykuwa opinia M. Skrzypka. Nie on jeden odważył się wskazywać coś, czego nie ma we współczesnych podręcznikach socjologii, a co znajduje dziś potwierdzenie w egzystencjalnym doświadczeniu mieszkańców wielkich miast. Wybrałam ten przykład jako jedną z przyciągających moją uwagę myśli z XI Kongresu Obywatelskiego z roku 2017. Świadectwo to obrazuje zmianę tonu debaty, przeprowadzanej od lat w tej samej konwencji. Autor rozpoczyna poetycko:

Demontaż lokalności zaczyna się tam, gdzie przestaje opłacać się chodzenie pieszo [...]. Brak bliskości fizycznej przekłada się na zanik poczucia bliskości psychicznej, aksjologicznej i symbolicznej [...]. Nie chodzi o stosowanie zasady albo-albo - albo lokalność albo mobilność. Chodzi o zdrowe proporcje, o to, aby oparta na bliskości lokalność była podstawową komórką relacji ludzie-przestrzeń wszędzie, gdzie to możliwe (Skrzypek 2017, s. 149 i nast.).

Mamy tu przykład argumentacji, która sytuuje się w wąskim przesmyku pomiędzy Scyllą (ojkofiią) a Charybdą (ojkofobią). Nowy klimat intelektualny skierowany na poszukiwanie równoważenia relacji między ludźmi, docenienie procedur prowadzących do „uwspólniania” ich doświadczenia oraz odkrycie efektu synergii w życiu społecznym, niezależnie od upraszczających kategorii socjologicznych, prowadzi w stronę wsi. Fizycznie dostępna przestrzeń wsi jest dla ludzi trwałym składnikiem ich lokalnej wiedzy i doświadczenia. Wiedzy, której formą jest tradycja uważana nie za przebrzmiały zwyczaj, lecz za mądrość kierującą pytaniem, co zrobić, aby dostosować swoje postępowanie do potrzeb tych, którzy byli przed nami i następują po nas. Wspomniany M. Skrzypek z Kongresu Obywatelskiego nieprzypadkowo opatrzył swoją wypowiedź tytułem „Mądrość roju [...]", chodzi bowiem - jak w kulturze - o znajdowanie odpowiedzi na nieprzemijające pytania.

Doświadczenie - słowo kluczowe dla współczesnego dyskursu w humanistyce - odsłania jego nowe znaczenie, które - nie tak jak u Arystotelesa - odnosi się do ludzi mądrych, bo doświadczonych, ale przeciwnie - bywa wątpliwe, niepewne. Przez tę swoją cechę doświadczenie cenione jest też w etosie demokratycznym, ponieważ ma charakter relacyjny, czyli włącza w dialog doświadczenie kogoś innego. À propos, zapamiętałam rozmowę, którą swego czasu prowadził redaktor R. Stawiszyński z profesor Z. Rosińską w programie Niedziela filozofów właśnie na temat doświadczenia. Zapadło mi w pamięć zdanie: „Dobrze jest, jak człowiek ma w sobie trochę niepewności, bo staje się (tym samym) otwarty, słucha drugiego" (Radio Dla Ciebie, 12.10.2014). W takich okolicznościach nie tylko doświadczenie eksperckie, wyrażone w raportach, ale jednostkowe, bezpośrednie, osobiste przeżycie ludzi ma równe znaczenie. Ranga doświadczenia rośnie też dlatego, że - paradoksalnie - mamy do czynienia z fenomenem ,zaniku doświadczenia” jako 
efektu zmienionych technologicznie warunków życia. Kiedy doświadczenie codzienności, na przykład rolników, mieszkańców wsi, zostaje kolizyjnie zderzone z interesami innych grup - inwestorów, nowych osadników, rezydentów - możemy mówić o zjawisku bagatelizowania doświadczenia środowiska na tle przemożnej siły interesu lub postaw typowych dla „technofilii”. Wówczas faktycznie, wobec napędzanego konsumpcją powierzchownego „gadżeciarstwa”, które opanowało kulturę popularną, i wobec dominujących okoliczności życia, głębsze doświadczenie ulega pomniejszeniu.

Kategoria doświadczenia odgrywa istotną rolę w strukturze ludzkiego poznania. Powodem takiego stanu rzeczy jest fakt, że to, co w pozytywistycznym modelu wiedzy naukowej uchodziło za metafizyczne, a tym samym nienaukowe, zaczyna poszerzać i pogłębiać możliwości poznania. Postawa intelektualna współczesnego badacza spraw społecznych nie zamyka go na takie przejawy ludzkich relacji z otoczeniem i innymi ludźmi, jak uczucia i emocje. Doświadczenie jako kategoria poznania staje się swego rodzaju ,,przepustką" do odzyskania tego, co $\mathrm{w}$,strumieniu życia” istotne.

Życiowe doświadczenie ludzi, a nie ,pojęć i liczb” (Bucholc 2012, s. XLVII) urasta w humanistyce do kluczowej kategorii, geografia kulturowa staje się zaś na tym tle dyscypliną wiodącą. Stąd także w badaniach geograficznych dotyczących rolnictwa obserwuje się zwrot $\mathrm{w}$ stronę ,różnych przejawów gospodarowania człowieka w wiejskiej przestrzeni" (Wójcik 2012, s. 154). Pogłębienie refleksji nad społeczno-kulturowym wymiarem badań jest traktowane jako konieczne zaplecze teoretyczno-metodologiczne nowej geografii wsi. Przykładem odejścia $w$ jej programie od wzoru geografii społeczno-ekonomicznej były pierwsze dyskusje na temat wyobrażenia i postrzegania wsi przez jej mieszkańców. Geografowie prowadzący te studia byli nie tylko pod urokiem, ale także pod wpływem badań antropologów społecznych i psychologów środowiskowych (Wójcik 2012, s. 200).

Analiza ludzkich doświadczeń obcowania z przestrzenią - w tym zmysłowych, cielesnych, uczuciowych - jest efektem wyczulenia na kulturowy zwrot, a zarazem ilustracją zwrotu przestrzennego (spatial turn). Przez ten pryzmat do nowego słownika badań przestrzennych wchodzą takie określenia, jak: duch miejsca (genius loci), atmosfera miejsca, wyimaginowane miejsca, przestrzeń hybrydalna, przestrzeń utowarowiona, przestrzeń dyscyplinarna (Giddens 2003, s. 189, 192), społeczna reprezentacja przestrzeni (social representation), topophilia, krajobraz kulturowy, ale też: przestrzenie tranzytowe, nie-miejsca.

Jednym z kluczowych pojęć w geografii humanistycznej jest „miejsce”. Nie siląc się na systematyczny przegląd rozumienia i określania tego terminu, jako że 
informacje na ten temat można odnaleźć w obfitej już literaturze (Libura 1990), zwrócę tylko uwagę na jego aspekt, który łączy się właśnie z ludzkim doświadczeniem środowiska życia. Miejsca dają ludziom poczucie zadomowienia, zamieszkiwania, osadzenia - zarówno w sensie przywiązania z wyboru, jak i z konieczności (więzienie jako przestrzeń dyscyplinująca) - oswojenia, identyfikacji. Geografia z „ludzką twarzą”, otwierając się na refleksję humanistyczną, czerpie z francuskiej szkoły géographie humaine, także z dorobku symbolicznego interakcjonizmu, fenomenologii, szczególnie zaś z prac E. Husserla i A. Schütza. Dodałabym też uczniów Husserla, takich jak: M. Scheler, E. Stein, M. Heidegger. Zainspirowali oni nie tylko geografów humanistycznych do zainteresowania się ludzką komunikacją i światem życia codziennego jako przestrzenią intersubiektywności. Zwrócenie uwagi na fakt, że nie jest to świat postrzegany jako ,suma obiektów i faktów, ale jako system relacji pomiędzy człowiekiem i jego otoczeniem" (Libura 1990, s. 25), łączy perspektywę geografii humanistycznej z bliską mi orientacją w badaniach wsi (Wieruszewska 1991).

Niektórzy socjologowie mogliby w tym miejscu przytoczyć argumenty za unieważnieniem we współczesnych przemianach nie tylko kategorii doświadczenia, miejsca, ale szerzej - w ogóle wymiaru przestrzennego - tak jak go powyżej opisałam. Przejawy tego nastawienia dostrzegam na przykład w powszechnym wypieraniu pojęcia miejsca czy terytorium przez termin „obszar” jako kopii rural areas, czyli łatwej i prostej kalki z języka angielskiego.

W tym miejscu odwołam się do szeroko rozpropagowanej tezy o osłabieniu, jeśli nie wręcz zaniku izomorfizmu pomiędzy fizycznym terytorium, ludźmi je zamieszkującymi i właściwą im kulturą lokalną. To tylko część prawdy. Nie negując bowiem wpływu globalizacji oraz nowych technologii, które faktycznie interweniują w konteksty przestrzenne, nie należy zamykać oczu na zjawiska odwrotne do deterytorializacji. Już M. Castells pokazywał, że poza „przestrzenią przepływów" nadal trwa konkretna, namacalna przestrzeń fizyczna jako budulec konkretnych miejsc (Lukasik 2015, s. 227). Słusznie zatem uważa się, iż w odróżnieniu od poprzedniej epoki kulturę (w tym ludzkie doświadczenie i język ekspresji) zdominowały raczej kategorie przestrzeni, a nie czasu, jak to było w okresie tzw. wysokiej moderny. Warto przypomnieć, że kategoria czasu, silnie obecna w ewolucjonizmie, traci swą moc wyjaśniającą nie tylko z racji podważenia idei jednokierunkowego rozwoju, lecz także ze względu na niemożność uchwycenia „globalnych równoczesności” naszego świata. Żyjemy wszak w ,płynnej rzeczywistości", raczej synchronii niż diachronii (Jameson 1986, za: Bachman-Medick 2012, s. 335), w krzyżujących się napięciach różnych procesów o przeciwstawnych wektorach. Mamy do czynienia ze znikaniem procesów i nieoczekiwanym 
pojawianiem się ich w nowych konstelacjach. Widzimy też odwroty i powroty rozmaitych ujęć przestrzeni: od tradycyjnego jej przedstawiania jako zasobnika lub kontenera po jej usieciowienie, któremu wtóruje chęć przezwyciężenia esencjalizmu. Kierunek refleksji przebiega od rematerializacji, nad którą wisi groźba „naturalizacji i pozytywizacji” (Bachmann-Medic 2012, s. 336, 370, 383, 385), po wizualne symbolizacje. $Z$ drugiej strony ujęcia przestrzeni przebiegają w kierunku od realności do sfery wyobrażeniowej, mentalnej, konstruowanej. Wagi nabierają zarówno relacyjne pojęcie przestrzeni, jak i praktyki jej kształtowania. Trzeba odnotować, iż krytyczne i sceptyczne pojęcia przestrzeni ujmowanej przez pryzmat omawianego „zwrotu”, wyrastają ze skojarzeń z ideologiami przebrzmiałymi (rasistowska ideologia ziemi i krwi), ale też aktualnymi postkolonialnymi. W tym układzie pojawia się jeszcze inny, otwarty koncept przestrzeni jako thirdspace, czyli takiej, w której dochodzi do nawarstwienia się miejsc realnych i wyobrażonych (Bachmann-Medic 2012, s. 356). Przez filtr obustronnych relacji pomiędzy człowiekiem i przestrzenią udaje się dostrzec swego rodzaju kontrprocesy, które wyłamują się z jednostronnych opisów efektów globalizacji. Widać to choćby na przykładzie reterytorializacji. Przestrzeń doświadczana jako mała ojczyzna, sąsiedztwo, otoczenie czy krajobraz jest interpretowana w duchu ojkofilii jako podstawa do zaistnienia szczególnej atmosfery wywołanej codziennymi relacjami ludzi w znajomym środowisku lokalnym. Transnarodowe przestrzenie zglobalizowanego świata oddają wprawdzie ogólny charakter kulturowej dynamiki, ale w mikroskali pozwalają odsłonić nowe zjawiska, które są konieczne do podtrzymania i ochrony wspólnej płaszczyzny porozumienia - warunku sine qua non tzw. ,inteligentnej przestrzeni” (Bach-Głowińska 2014, s. 171, 185).

Na przejawy kontrprocesów we współczesnej globalizacji szybciej niż w Polsce zareagowano w Wielkiej Brytanii w odniesieniu do programu edukacji szkolnej. O ile w polskich podręcznikach wciąż dominuje koncepcja urbanizacji przestrzeni, przedstawiana w kategoriach ilościowych, to w podręcznikach angielskich sprawa wygląda zupełnie inaczej. Różny sposób podejścia do nauczania geografii w Polsce i Wielkiej Brytanii jest, na co wskazuje P. Tobiasz-Lis, pochodną innych wzorów teoretyczno-metodologicznych ${ }^{4}$. Angielscy uczniowie są zachęcani do samodzielnego, refleksyjnego i zarazem problemowego ujmowania zjawisk przestrzennych. Są też motywowani do analizowania sytuacji życia codziennego ludzi, konceptualizowania i interpretowania problemów, a nie tylko faktów (Tobiasz-Lis 2015, s. 169). Zakładam, że tego rodzaju przygotowanie pozwoli na po-

${ }^{4}$ Obciążenie założeniami ewolucjonizmu, które wciąż dotykają niektórych dyscyplin w Polsce, niestety wikła je w pułapki postępu i rozwoju. 
szerzenie horyzontu, bez czego trudno byłoby zrozumieć to, że przestrzeń, w której żyjemy, ma odległe wzorce w przeszłości (Kossow 2007).

Trzeci rodzaj zwrotu, dopełniającego zbiór przesłanek dla podjęcia tematu percepcji wizualnej krajobrazu kulturowego wsi, odnosi się do rewolucji w dziedzinie obrazu, która przyjęła nazwę iconic turn ${ }^{5}$. Wszystkie zwroty - kulturowy, przestrzenny i ikoniczny - są ze sobą powiązane, zatem nie pojawiły się w ostatnim czasie niezależnie od siebie. Pomimo tego, że łączymy je z postmodernizmem, to ich wspólnego źródła (zdecydowanie wcześniejszego) należy dopatrywać się w stopniowo narastającej krytyce poznania. Nie są bynajmniej fenomenami wyłącznie XXI w., chociaż ten wiek szczególnie wyostrzył i poszerzył implikacje badawcze, które pod ich wpływem zachodzą w różnych dyscyplinach humanistyki. Jak zauważa D. Bachmann-Medick, zwrot ikoniczny „pojawia się jako topos powtarzający się we wszystkich medialnych przełomach od fotografii po Internet, w których wizualność wyznacza historyczny punkt zwrotny" (Bachmann-Medick 2012, s. 395). Wizualność odwołuje się do osobowej percepcji i jednocześnie do kolektywnej symbolizacji, przez co rozszerza fenomen postrzegania poza status zewnętrznego obiektu. Jak pisze dalej autorka:

Obraz konstytuuje się dopiero $\mathrm{w}$ toku wchodzenia $\mathrm{z}$ nim $\mathbf{w}$ relacje [podkr. - M.W.], w szczególności pod wpływem kulturowych konwencji percepcji [...]. Kompleksowość analizy obrazu [obejmuje] także aspekty wytwarzania obrazów w przestrzeni społecznej, aktywność zmysłowego postrzegania [...] wewnętrznych obrazów (Bachmann-Medick 2012, s. 399).

Łatwo da się w takiej perspektywie dostrzec przezwyciężenie dualizmu wewnętrzności i zewnętrzności oraz wyraźny przykład ,zdekonstruowanych opozycji” i „podważonych binaryzmów”, które łamią opozycję Natura-Kultura (Bator 2008, s. 15). Tworzące ją przeciwieństwa, które myśl naukowa i krytyczna kierowały w stronę obrazów, takie jak: „forma i treść, znaczony i znaczący, wewnętrzny i zewnętrzny, sensualny i konceptualny itp. zawsze przychodziły zbyt p ó ź n o, jak gdyby obraz ulokował się w innym logicznym świecie, którego zasad nie znamy" (Boehm, Mitchell 2012, s. 104) ${ }^{6}$. To sprawia, że akcent jest przesuwany na widzenie, postrzeganie, obserwowanie, „formowanie spojrzenia” jako społeczno-kulturową praktykę. Nowy zwrot (visual turn) jest tworzony nie tylko

\footnotetext{
${ }^{5}$ Określenia ,zwrot ikoniczny” (iconic turn) i ,zwrot obrazowy” (pictorial turn) zostały wyjaśnione przez G. Boehm i W.J.T. Mitchella w korespondencji, którą między sobą prowadzili (zob. Boehm, Mitchell 2012).

${ }^{6}$ Ta właściwość doświadczenia, które obejmuje wizualną percepcję obrazów, jest wykorzystywana do podważenia paradygmatu kartezjańskiego z właściwym mu dualizmem treści i formy poznania.
} 
przez samą fizyczną „optyczność”, fizykę oka traktowanego jak „otwór gębowy" oraz bezpośrednią naoczność, lecz również przez wielowarstwowy kontekst „przemiennej gry” wizualności, symbolizacji, dyskursu i wspomagania technologicznego.

Poprzez kulturę wizualną eksponowana jest skłonność do obrazowania i wizualizacji ludzkiej egzystencji. Nieprzypadkowo współczesna parafraza powiedzenia Kartezjusza mogłaby brzmieć: „widzą mnie, więc jestem”. Charakteryzowanie współczesnego społeczeństwa za pomocą takich określeń, jak: tyrania wizualna, imperializm wizualny, reżim wizualny, społeczeństwo spektaklu, ikon, designu, autoprezentacji, podglądania, to przykład powszechnej obecnie tendencji ${ }^{7}$.

Warto w tym miejscu poszerzyć refleksję o wymiar cywilizacyjny, tym bardziej że wizualność ujmowana jest na tle właściwości kultury zachodniej. Sedno debaty sprowadza się do wskazania wyróżnika przeciwstawiającego zachodni krąg cywilizacyjny temu, co do niego nie należy. W postmodernistycznej dyskusji, do której dołączają się też młodzi polscy badacze (Angutek 2013, Jeziorski 2013), próbuje się stworzyć nową ontologię rzeczy w opozycji do kultury naukowej świata zachodniego. Na cenzurowanym - co mnie dziwi - jest „zachodni uniwersalizm" i ,zaślepienie strukturalnym substancjalizmem”, ale też tzw. okulocentryzm, który uprzywilejowuje wzrok na tle pozostałych zmysłów. Postmodernistyczni badacze, w modnej postkolonialnej konwencji, postrzegają zachodni okulocentryzm jako instrument władzy i panowania nad innymi. Wpisywanie się w taki ton krytyki i stawianie w centrum zainteresowania całej myśli Zachodu, której przypisuje się „odwieczną dyktaturę bytu ludzkiego” (Olsen 2013, s. 12) jest - w moim odczuciu - mocno przesadzone. Nie można pominąć sporu dotyczącego tego, co w poznaniu ludzkim jest $\mathrm{z}$ jednej strony językowe, pojęciowe, tekstowe, z drugiej zaś - obrazowe. „Detronizowanie wzroku”, jakoby uprzywilejowanego przez Zachód, nie dopuszcza innej refleksji. To kultura zachodnia faworyzowała słowo, ,jako najwyższą formę praktyki intelektualnej”, zostawiając obrazowaniu i wizualności podrzędną funkcję ilustracji pojęć (Mirzoeff 2012, s. 163). Wystarczy odwołać się do myśli Platona, by dostrzec jego rozróżnienie na wiedzę niezawodną dzięki pracy rozumu (episteme) i zawodną opartą na zmysłach i doświadczeniu materialności (doxa). W samej kulturze zachodniej dyskusja przebiega zatem według porządku preferencji i jednocześnie nadrzędności i podrzędności w ludzkim poznaniu. Wskazanie na multisensoryczność - w tym: słuch, węch, dotyk, a nie tylko wzrok - w ludzkim doświadczeniu nie może oznaczać

7 „Podczas gdy wizualizowanie było powszechne w okresie nowoczesnym, obecnie stało się prawie obowiązkowe" (Mirzoeff 2012, s. 162). 
mojej zgody na stygmatyzującą etykietę okulocentryczności kultury zachodniej. Nie ukrywam, że był to nie mniej ważny niż wcześniej opisane motyw podjęcia tematu percepcji wizualnej krajobrazu kulturowego wsi.

\section{Literatura}

Albrow M., 1996, The Global Age, Cambridge.

Angutek D., 2013, Kulturowe wymiary krajobrazu. Antropologiczne studium recepcji przyrody na prowincji: od teorii do empirii, Poznań.

Bach-Głowińska J., 2014, Inteligentna przestrzeń. Trzeci wymiar innowacyjności, Warszawa.

Bachmann-Medick D., 2012, Cultural turns. Nowe kierunki w naukach o kulturze, przekł. K. Krzemieniowa, Warszawa.

Bator J., 2008, Wstęp. Metafory i metonimie ptci, [w:] Bator J., Wieczorkiewicz A. (red.), Ucieleśnienia II. Płeć między ciatem i tekstem. Praca zbiorowa, Warszawa, s. 7-19.

Bucholc M., 2012, Wstęp [do:] Maffesoli M., Rytm życia. Wariacje na temat wyobraźni ponowoczesnej, przekł. A. Karpowicz, Kraków, s. XL-XXXV.

Bukraba-Rylska I., Wieruszewska M., Burdyka K., 2017, Lokalne dziedzictwo kulturowe $w$ doświadczeniu mieszkańców wsi, Warszawa.

Bohem G., Mitchell W.J.T., 2012, Zwrot obrazowy a zwrot ikoniczny: dwa listy, [w:] Bogunia-Borowska M., Sztompka P. (red.), Fotospołeczeństwo. Antologia tekstów z socjologii wizualnej, Kraków, s. 94-117.

Giddens A., 2003, Stanowienie społeczeństwa. Zarys teorii strukturacji, przekł. S. Amsterdamski, Poznań.

Jameson F., 1986, Postmoderne - Zur Logik der Kultur im Spät-kapitalismus, [w:] Huyssen A., Scherpe K.R. (red.), Postmoderne. Zeichen eines kulturellen Wandels, Reinbek, s. $45-102$.

Jeziorski I., 2013, Krawędzie doświadczenia. Studium z antropologii wizualnej i sensorycznej, Bielsko-Biała.

Kowicki M., 2011, O wątpliwych i niewątpliwych pożytkach z badań naukowych na temat wsi w planowaniu przestrzennym i architekturze, [w:] Halamska M. (red.), Wieś jako przedmiot badań naukowych na początku XXI wieku, Warszawa, s. 73-87.

Kossow M., 2007, Spoleczne wytwarzanie przestrzeni w Starym Testamencie, „Studia Regionalne i Lokalne", 2 (28), s. 13-26.

Libura H., 1990, Percepcja przestrzeni miejskiej, seria: Rozwój Regionalny, Rozwój Lokalny, Samorząd Terytorialny, 31, Warszawa.

Łukasik M., 2015, Lokalność w kontekście architektury i atmosfery, „Societas/Communitas”, 1-2 (19-20), s. 224-229. 
Mirzoeff N., 2012, Czym jest kultura wizualna?, [w:] Bogunia-Borowska M., Sztompka P. (red.), Fotospoleczeństwo. Antologia tekstów z socjologii wizualnej, Kraków, s. 158-192.

Olsen B., 2013, W obronie rzeczy. Archeologia i ontologia przedmiotów, przekł. B. Shallcross, Warszawa.

Scruton R., 2017, Zielona filozofia. Jak poważnie myśleć o naszej planecie, przeł. J. Grzegorczyk, R.P. Wierzchosławski, Poznań.

Skrzypek M., 2017, Mądrość roju - czyli mechanizm rozwoju wspólnot lokalnych, [w:] Szomburg J. (red.), Polacy i Polska wobec wyzwań dojrzałości. Po XI Kongresie Obywatelskim, Gdańsk, s. 149-155.

Sztompka P., 2007, Zaufanie. Fundament społeczeństwa, Kraków.

Tobiasz-Lis P., 2015, Obraz wsi i rolnictwa w polskich $i$ angielskich podręcznikach do geografii, „Studia Obszarów Wiejskich”, 40, s. 169-179.

Wieruszewska M., 1991, Wieś. W poszukiwaniu całości społeczno-kulturowej, Warszawa.

Wieruszewska M., 2017a, Krajobraz kulturowy wsi w percepcji wizualnej, [w:] Bukraba-Rylska I., Wieruszewska M., Burdyka K., Lokalne dziedzictwo kulturowe w doświadczeniu mieszkańców wsi, Warszawa, s. 45-80.

Wieruszewska M., 2017b, The Rural Cultural Landscape in Visual Perception, [w:] Bukraba-Rylska I., Wieruszewska M., Burdyka K., Lokalne dziedzictwo kulturowe w doświadczeniu mieszkańców wsi, Warszawa, s. 219-225.

Wilkin J., 2016, Instytucjonalne i kulturowe podstawy gospodarowania. Humanistyczna perspektywa ekonomii, Warszawa.

Wójcik M., 2012, Geografia wsi w Polsce. Studium zmiany podstaw teoretyczno-metodologicznych, Łódź.

\section{Programy radiowe}

Radio Dla Ciebie, 12.10.2014 r.

\section{On the need for research on visual perception of rural cultural landscape}

\section{Summary}

The article presents the argumentation for the issue of the rural cultural landscape in visual perception. The Author conducts her reflection in the light of three turns, namely: cultural, iconic and the spatial one. She stressed that the degraded rural environment as well as demolished cultural landscape is the proof of erroneous theoretical and methodological assumption of research. She points the wrong patterns of spatial planning as consequences of the lack of humanistic view in disciplines dealing with space. The critical reflection against the lack of such values as: love of home and localities, tradition, respect for space in historical and geographical aspects is the main axis of the author's narration. The more 
humanistic approach is badly needed to implement the requirement of geography with "human face".

According to Author, who has shared the Roger Scruton's opinion, the protection of the rural cultural landscape requires the strong appreciation the conservative values of culture, rather than "progressive" ones. At the end of the text she argue the tendency - observed among some young researchers - to diminish the role of sight in human experience because of his affiliation to the West. She tried to challenge the "culture of rejection" (of sight) as the important factor of human - sensitive and intellectual - experience helping against the demolition and annihilation of polish villages.

Keywords: cultural turn, iconic turn, spatial turn, rural community, values.

Prof. dr hab. Maria Wieruszewska

Polska Akademia Nauk

Instytut Rozwoju Wsi i Rolnictwa

ul. Nowy Świat 72, 00-330 Warszawa

e-mail: maria.wieruszewska@irwirpan.waw.pl 